\title{
Root Surface Bio-modification with Erbium Lasers- A Myth or a Reality??
}

\author{
Vamsi Lavu, Subramoniam Sundaram, Ram Sabarish and Suresh Ranga Rao* \\ Department of Periodontics, Faculty of Dental Sciences, Sri Ramachandra University, Porur, Tamil Nadu, Chennai, \\ India
}

\begin{abstract}
The objective of this literature review was to critically review the evidence available in the literature regarding the expediency of erbium family of lasers for root bio modification as a part of periodontal therapy. The literature search was performed on the Pubmed using MeSH words such as "lasers/therapeutic use, scaling, dental calculus, tooth root/anatomy and histology, ultrasonic therapy". The studies were screened and were grouped as follows: those evaluating a) efficacy for calculus removal with the Erbium family of laser b) root surface changes following Er YAG and Er Cr YSGG application c) comparative studies of the Er YAG, Er Cr YSGG lasers versus conventional methods of root surface modification d) Bio compatibility of root surface following Erbium laser treatment e) Studies on the combined efficacy of laser root modification with conventional methods towards root surface bio-modification $f$ ) Studies on effectiveness of root surface bio-modification prior to root coverage procedures. In conclusion, the erbium family has a proven antibacterial action, predictable calculus removal, minimal root substance removal, and appears to favor cell attachment. The Erbium family of lasers appears to be a useful adjunct for the management of periodontal disease.
\end{abstract}

Keywords: Cementum, dental calculus, Er-YAG lasers, non-surgical therapy, periodontitis, root bio-modification.

\section{INTRODUCTION}

One of the most challenging aspects of periodontal therapy is the development of a predictable approach for root surface modification. Root surface modification gains importance due to the fact that the biofilm contributes to root surface changes which impair regeneration attempts. In order to achieve an understanding of why regeneration attempts succeed or fail, knowledge of root surface changes in periodontal disease and its clinical implication becomes essential.

\section{A BRIEF OVERVIEW OF ROOT SURFACE CHANGES IN PERIODONTAL DISEASE}

The etiology of periodontitis is bacteria which attach to the root surface and thrive in a biofilm environment. These bacteria later become partially mineralized to form calculus. A portion of the bacteria remains unattached, float freely in the gingival crevicular area and are commonly responsible for tissue invasion of the periodontium, resulting in a variety of host bacterial interactions which manifest clinically as periodontal disease [1].

The root surface undergoes a series of changes in its physical, chemical nature and also becomes cytotoxic due to the release of bacterial toxins that get attached to the root cementum. Broadly, the changes include a loss of fiber attachment from the cementum area (physical) [2], demineralization of the root surface forming craters/ root caries (chemical changes) [3] and lipopolysaccharide attachment to cementum surface (necrotic / altered cementum) [4].

*Address correspondence to this author at the Department of Periodontics, Faculty of Dental Sciences, Sri Ramachandra University, No.1 Ramachandra Nagar, Porur, Chennai - 600116, Tamil Nadu, India;

Tel: +91-44-2476-8027, Extn: 8256; E-mail: chennaidentist@gmail.com

\section{Rationale for Root Bio-modification}

The factors influencing successful periodontal therapeutic outcomes (regeneration) include [5]

1. Clot stability.

2. Cell migration towards the root surface.

3. Cell attachment.

4. Cell proliferation and differentiation.

The root surface properties play an important role in all the above mentioned events as established by Polson and Caton [6] who postulated that ideal root surface should be free of contaminants and superficial layer of hypermineralized cementum. Therefore preparation of a root surface which is favorable for the above mentioned events constitutes the rationale behind root bio-modification.

\section{Root Modification/Bio-modification}

Root bio-modification refers to procedures which are done to de-toxify, de-contaminate and de- mineralize the root surface, thereby removing the smear layer and exposing the collagenous matrix of dentin and cementum [7]. The oldest and the most conventional methods include scaling and root planing which are primarily aimed at the gross removal of microbes from the root surface. The scaling and root planing had a limitation in that; it also resulted in removal of cementum and formation of smear layer [8]. This was followed by the advent of root conditioning agents,

Root conditioning agents aimed at the removal of the smear layer [9] produced during scaling and root planing to expose the dentinal tubules and dentinal collagen (to favor the joining of the Sharpey's fibers with root collagen). This modality gave way to application of fibronectin and recom- 
binant forms of growth factors such as PDGF, BMP, enamel matrix proteins [10]. These factors provided the signals for the cell chemotaxis, attachment, proliferation and differentiation. The use of recombinant growth factors for root biomodification is limited as they are expensive and cannot be used as a mono-therapy. In addition, a cocktail of growth factors which act in a sequential manner are needed to obtain a successful periodontal regeneration. Amongst, the above mentioned modalities of treatment only EMDOGAIN (enamel matrix proteins) have demonstrated new cementum formation [11].

A significant step towards successful periodontal regeneration could be attained if the surface contaminants could be removed with minimum damage to underlying cementum. In this regard, the Erbium lasers represent a potential therapeutic tool. A summary of the various root bio-modification agents used are provided in Table $\mathbf{1}$.

\section{LASERS AS A THERAPEUTIC MODALITY FOR ROOT SURFACE MODIFICATION}

The effect of laser on any given tissue depends on the optical properties of the tissue on which it is incident. The root surface is composed of cementum primarily and in a few cases dentinal tubules exposed at the cemento-enamel junction. Water and hydroxyapatite serve as the chromophores (substance which can absorb the radiation of a particular wavelength). As a result only lasers which are absorbed in these chromophores demonstrate adequate therapeutic ability in root surface modification. These include the erbium family of lasers (Er YAG, Er YSGG), CO2 lasers, Holmium YAG (Yttrium Aluminum Garnet) laser. Among these, the erbium family has shown considerable promise for the purpose of root modification [22].

The Erbium family which includes the erbium YAG (Yttrium Aluminium Garnet) and Erbium chromium YSGG (Yttrium Scandium Gallium Garnet) are solid phase lasers wherein the Yttrium Garnet crystals are doped with Alumin- ium or Scandium and Gallium. The wavelength of the Erbium YAG is $2940 \mathrm{~nm}$ and Er: Cr YSGG $2780 \mathrm{~nm}$ respectively. The Erbium: YAG laser belongs to the near infra red spectrum and it has proven efficacy in ablation of dental hard tissue $[23,24]$.

The unique properties [25] of the Erbium laser family include

1. High absorption in water as compared to Carbon dioxide (CO2) / Neodymium Yttrium Aluminium Garnet (Nd:YAG) lasers.

\section{Good absorption in hydroxyapatite}

3. Minimal thermal damage to the soft / hard tissue on which it is incident.

The incident laser beam is absorbed by water which undergoes a rapid thermal expansion and induces microexplosions and removal of the hard tissue (enamel, dentin and bone). The erbium family of lasers is used with water (irrigant) and the amount of water flow influences the efficacy and depth of penetration of the laser in the tissue [24].

\section{Methodology for Literature Review}

The literature review was performed by conducting a search on PubMed/ Medline using a combination of the MeSH Words "Er: YAG lasers, YSGG Lasers, root scaling, dental calculus, tooth root, ultrasonic therapy". The available literature was then compiled and the various studies were grouped under the following heads as follows:

Studies evaluating the:

a). Efficacy of Erbium family of lasers for calculus removal.

b). Root surface changes following $\mathrm{Er} Y \mathrm{YG}$ and $\mathrm{Er} \mathrm{Cr}$ YSGG application.

c). Comparative studies of the Er YAG, Er Cr YSGG lasers versus conventional methods of root surface modification.

Table 1. Root conditioning agents used in periodontal therapy.

\begin{tabular}{|c|c|c|c|}
\hline Agent used & Method of use & Advantages & Limitations \\
\hline Citric Acid & $\begin{array}{l}\text { pH 1.0. Topical application on root surface for } \\
2-3 \text { minutes after scaling and root planing. }\end{array}$ & Removal of smear layer [9]. & $\begin{array}{l}\text { No predictable regeneration [12]. } \\
\text { pH acidic and can be unfavorable for cell } \\
\text { attachment [13]. }\end{array}$ \\
\hline Tetracycline & $\begin{array}{l}100 \mathrm{mg} / \mathrm{ml} \text { solution. Topical application on } \\
\text { root surface for } 5 \text { minutes after scaling and } \\
\text { root planing. }\end{array}$ & $\begin{array}{l}\text { Anti-collagenase and anti-microbial activity } \\
{[14] .} \\
\text { Smear layer removal }[15] .\end{array}$ & $\begin{array}{l}\text { No significant gain in attachment reported } \\
\text { [12]. }\end{array}$ \\
\hline Fibronectin & $0.38 \mathrm{mg} / \mathrm{ml}$ solution- topical application. & $\begin{array}{l}\text { Promotes cell adhesion to root surface and } \\
\text { chemotactic effect on periodontal fibroblasts } \\
{[16] .}\end{array}$ & $\begin{array}{l}\text { Ineffective when used alone. When com- } \\
\text { bined with citric acid, better clinical at- } \\
\text { tachment level gain [17]. }\end{array}$ \\
\hline EDTA & $\begin{array}{l}2 \text { concentrations have been used ( } 8 \% \text { and } \\
24 \% \text { ). The } 24 \% \text { concentration had neutral ph } \\
(7.0-7.2) \text {. Topical application on root surface } \\
\text { for } 2-3 \text { minutes after scaling and root planing }\end{array}$ & $\begin{array}{l}\text { Effective smear layer removal }[18] . \\
\text { Neutral pH favors cell migration and attach- } \\
\text { ment [19]. }\end{array}$ & $\begin{array}{l}\text { Ineffective when used alone. When used } \\
\text { with Emdogain, periodontal regeneration } \\
\text { has been demonstrated [20]. }\end{array}$ \\
\hline EMDOGAIN & $\begin{array}{l}\text { A combination of enamel matrix proteins. } \\
\text { Bio-mimetic concept. } \\
\text { Used along with } 24 \% \text { EDTA. }\end{array}$ & $\begin{array}{l}\text { Acellular cementum formation has been } \\
\text { demonstrated [21]. }\end{array}$ & Cost is prohibitive \\
\hline
\end{tabular}


d). Biocompatibility of root surface following Erbium laser treatment.

e). Combined efficacy of laser root modification and conventional methods towards root surface bio-modification.

f). Effectiveness of root surface bio-modification prior to root coverage procedures.

\section{CALCULUS REMOVAL FOLLOWING ERBIUM LA- SER APPLICATION}

The Erbium family has been found to be an efficient tool for calculus removal from the root surface with minimal thermal damage to the cementum. This is evidenced in numerous studies which have been summarized in Table 2. In recent times, the removal of calculus has been made more predictable due to the development of a "fluorescence feedback system". This system was developed based on the findings of a study by Folwaczny et al. [26] who demonstrated a strong fluorescence in sub-gingival calculus when exposed to $655 \mathrm{~nm}$ diode laser irradiation. This principle has been incorporated into an Er YAG laser unit which gets activated only if a certain threshold level for fluorescence of the root surface is exceeded. From the studies summarized in Table 2, it can be inferred that Erbium laser with fluorescent feedback provided a good alternative to conventional methods for calculus removal.

\section{Root Surface Changes and Parameters Influencing the Root Bio-modification with Erbium Lasers}

The Erbium family has a minimum penetration depth due to its high absorption in water. This entails a safe usage with minimum or no thermal damage to the root cementum and dentin. Studies have demonstrated variable changes in the root surface morphology depending on power setting and tip angulations used. Gaspric and Skaleric [38] demonstrated that a variation of energy applied $(60 \mathrm{~mJ}, 80 \mathrm{~mJ}$ and $100 \mathrm{~mJ})$ resulted in varying root surface morphology. At $60 \mathrm{~mJ}$, single craters were produced without deposits of melted mineral and exposed dentinal tubules. At $80 \mathrm{~mJ}$, numerous confluent craters were observed. At $100 \mathrm{~mJ}$, larger ablation defects were observed. Er :YAG laser when used at different power settings ranging from 25 to $100 \mathrm{~mJ} / \mathrm{sec}$ on the root surface in vitro produced a 15 micron layer of damaged tissue within the cementum, with an absence of Sharpey's fibers [39]. However, when used in vivo a smooth root surface was observed even at higher settings [30].

Angulations of the tip remain a significant factor influencing root surface roughness. Folwaczny et al. [40] evaluated the influence of various tip angulations $(15,30,45,60,90$ degrees) on root substance removal and surface roughness. A control group consisting of root surface instrumented with curettes was used. The authors observed no statistically significant difference in the roughness values of the root surface treated with laser and curettes. Also the differences in root substance removal were not significant when different angulations were used. The erbium family of lasers appears to be relatively safe at low energy settings and produce minimal root structure damage.

\section{Root Surface Bio-compatibility after Erbium Laser Therapy}

Studies have evaluated biocompatibility of the laser treated root surface in terms of

a. Elimination of endotoxin from the root surface.

b. Removal of the smear layer.

c. Reaction of cells to laser treated root surfaces (in vitro).

\section{Endotoxin Elimination from the Root Surface}

Endotoxin on the root surface contributes to the cytotoxic effects of the diseased root [4]. An in-vitro study on lipopolysaccharide removal from the root surface with Erbium laser revealed a $83.1 \%$ reduction of the lipopolysaccharide from the irradiated root surface [41] The endotoxin removal efficacy of erbium lasers has also been assessed by the chromogenic, quantitative Limulus - amoebocyte-lysate assay. The authors observed a reduction of LPS on root surface irradiated with erbium lasers and this reduction was proportional to the energy setting that is used [42]. Akiyama et al. [43] used SEM and transmission electron microscopy to determine the effect of Er:YAG laser on endotoxin. The authors found that Erbium laser ablates periodontopathic bacteria with thermal vaporization, and its bacterial elimination effect on the diseased root surfaces appears to be superior to that of the ultrasonic scaler. The observations of the above studies provide evidence for the effectiveness of the Erbium laser in managing the cytotoxic changes.

\section{Smear Layer Removal}

The formation of a smear layer consisting of dentinal debris and some bacteria occurs after scaling and root planing [8]. The removal of this smear layer assumes clinical importance due to the fact that the smear layer prevents attachment of connective tissue to the root surface. The hard tissue lasers such as the Erbium lasers have been proposed as an alternative to chemical conditioning of root surface for removal of smear layer. Recent studies [44, 45] compared the efficacy of smear layer removal by chemical root modification agents vs Erbium laser (Figs. $(\mathbf{1}, \mathbf{2})$ ). The authors have reported an equivalent and complete smear layer removal by erbium laser.

\section{Biological Reaction of the Cells to Erbium Treated Root Surfaces}

This assumes great importance as it represents one of the most important factors influencing success in periodontal regeneration. The various studies performed to assess the biologic reaction of cells of the periodontium to erbium laser treated root surface are summarized in Table $\mathbf{3}$. It can be inferred from these studies (Table 3 ) that a stable blood clot is formed and periodontal ligament fibroblast attachment is more favored on the laser treated root surface.

\section{Effectiveness of Combined Therapy in Root Modification}

Erbium lasers have also been used in combination with conventional methods such as acid conditioning of the root [56] and recombinant human growth factors (PDGF BB) [57] on periodontally involved root surfaces with improved fibroblast adhesion and proliferation being reported. 
Table 2. Summary of various studies performed comparing the efficacy of calculus removal using Erbium laser and conventional methods.

\begin{tabular}{|c|c|c|}
\hline $\begin{array}{l}\text { Aoki A et al. } \\
2000[27]\end{array}$ & $\begin{array}{l}53 \text { periodontally compromised teeth } \\
\text { Ultrasonic scaling Vs Erbium Laser }(40 \mathrm{~mJ} \text { per pulse and } 10 \text { pulses } \\
\text { under water spray) }\end{array}$ & $\begin{array}{l}\text { Laser scaling provided a level of calculus removal that was similar } \\
\text { to that provided by the ultrasonic scaling. } \\
\text { The Er:YAG laser produced superficial, structural and thermal } \\
\text { microchanges on the root cementum. }\end{array}$ \\
\hline $\begin{array}{l}\text { Schwarz F et al. } \\
2001[28]\end{array}$ & $\begin{array}{l}\text { Forty single rooted teeth } \\
\text { Ultrasonic scaling Vs Erbium Laser }(120 \mathrm{~mJ}, 140 \mathrm{~mJ}, 160 \mathrm{~mJ}, 180 \\
\mathrm{mJ} \text { at } 10 \mathrm{~Hz})\end{array}$ & $\begin{array}{l}\text { Er:YAG laser resulted in a smooth root surface morphology, even } \\
\text { at higher energy settings. The results also seem to indicate that } \\
\text { calculus removal can be selectively done in vivo }\end{array}$ \\
\hline $\begin{array}{l}\text { Frentzen M et al. } \\
2002[29]\end{array}$ & $\begin{array}{l}40 \text { extracted teeth } \\
\text { Ultrasonic scaling Vs Er YAG Laser }(160 \mathrm{~mJ} / \text { pulse, } 10 \mathrm{~Hz} .)\end{array}$ & $\begin{array}{l}\text { Laser scaling was accompanied by an increased removal of tissue } \\
\text { and roughened surfaces. } \\
\text { Laser scaling resulted in an increased loss of cementum and dentin. }\end{array}$ \\
\hline $\begin{array}{l}\text { Eberhard J et al. } \\
2003[30]\end{array}$ & $\begin{array}{l}\text { The mesial and distal surfaces of } 30 \text { single-rooted teeth with un- } \\
\text { treated periodontitis were treated either by hand instrumentation } \\
\text { (scaling and root planing (SRP)) or by Er:YAG laser irradiation } \\
(160 \mathrm{~mJ}, 10 \text { to } 15 \mathrm{~Hz})\end{array}$ & $\begin{array}{l}\text { Following laser irradiation, } 68.4 \pm 14.4 \% \text { of the root surface was } \\
\text { calculus free in contrast to } 93.9 \pm 3.7 \% \text { after SRP when both treat- } \\
\text { ments were performed for the same time }(2: 15 \pm 1: 00 \text { min). } \\
\text { The histologic evaluation showed that after SRP } 73.2 \% \text { of root } \\
\text { dentin was completely denuded from cementum, while only a } \\
\text { minimal cementum reduction was apparent after laser irradiation. }\end{array}$ \\
\hline $\begin{array}{l}\text { Schwarz F, et al. } \\
2006[31]\end{array}$ & $\begin{array}{l}72 \text { single-rooted teeth ( } \mathrm{n}=12 \text { patients) were randomly treated in } \\
\text { vivo by a single course of subgingival instrumentation using (1-3) } \\
\text { an Er: YAG laser (ERL1: } 100 \mathrm{~mJ} \text {; ERL2: } 120 \mathrm{~mJ} \text {; ERL3: } 140 \mathrm{~mJ} \text {; } \\
10 \mathrm{~Hz} \text { ), or (4) the Vector ultrasonic system (VUS) or (5) hand } \\
\text { instruments (SRP). }\end{array}$ & $\begin{array}{l}\text { Highest values of Residual subgingival calculus areas (RSC) }(\%) \\
\text { were observed in the SRP group }(12.5 \pm 6.9) \text {. ERL }(1-3)(7.8 \pm 5.8 \text {, } \\
8.6 \pm 4.5,6.2 \pm 3.9 \text {, respectively) revealed significantly lower RSC } \\
\text { areas than SRP. VUS }(2.4 \pm 1.8) \text { exhibited significantly lower RSC } \\
\text { areas than SRP and ERL }(1,2) \text {. }\end{array}$ \\
\hline $\begin{array}{l}\text { Moghare Abed A } \\
\text { et al. } 2007[32]\end{array}$ & $\begin{array}{l}\text { The mesial and distal surfaces of } 15 \text { periodontally loose extracted } \\
\text { teeth were treated randomly either by hand instrumentation or by } \\
\text { Er:YAG laser irradiation. }(160 \mathrm{~mJ}, 12 \mathrm{~Hz})\end{array}$ & $\begin{array}{l}\text { The surface roughness in Er: YAG laser group was more than in } \\
\text { hand instruments group. } \\
\text { Lower frequency and long pulse duration maybe more suitable for } \\
\text { the micro-morphology of root surface after treatment. }\end{array}$ \\
\hline $\begin{array}{l}\text { Krause F et al. } \\
2007[33]\end{array}$ & $\begin{array}{l}20 \text { teeth were treated with an Er: YAG laser. Laser settings were } \\
140 \mathrm{~mJ} \text { and } 10 \mathrm{~Hz} \text {. }\end{array}$ & $\begin{array}{l}\text { The amount of residual calculus following laser irradiation depends } \\
\text { on the fluorescence threshold level for a feedback-controlled Er: } \\
\text { YAG laser. }\end{array}$ \\
\hline $\begin{array}{l}\text { Hakki SS } \\
\text { et al. } 2010 \text { [35] }\end{array}$ & $\begin{array}{l}32 \text { single-rooted teeth were treated by different methods including } \\
\text { (1) conventional hand instruments; (2) hand instruments and tetra- } \\
\text { cycline-hydrochloride (Tet-HCl); (3) erbium, chromium:yttrium- } \\
\text { scandium-gallium-garnet (Er,Cr:YSGG) laser irradiation, setting I } \\
\text { (short pulse); (4) Er,Cr:YSGG laser irradiation, setting II (long } \\
\text { pulse). }\end{array}$ & $\begin{array}{l}\text { Roughness was greater in the long-pulse laser setting than in the } \\
\text { short-pulse setting. } \\
\text { All treatments were equally efficient in calculus removal from the } \\
\text { root surfaces. }\end{array}$ \\
\hline $\begin{array}{l}\text { Oliveira GJ et al. } \\
2012[36]\end{array}$ & $\begin{array}{l}60 \text { teeth samples were divided into } 3 \text { groups ( } 20 \text { each) } \\
\text { Group 1: Control (G1). } \\
\text { Group 2: Er Cr YSGG laser irradiation (G2). } \\
\text { Group 3: Er YAG laser irradiation (G3). } \\
\text { Out of the } 20 \text { samples in each group, } 10 \text { samples received blood } \\
\text { application. Root surface changes and blood component adhesion } \\
\text { was assessed by Scanning Electron Microscope (SEM). }\end{array}$ & $\begin{array}{l}\text { Teeth treated with Er: YAG and Er Cr YSGG lasers demonstrated } \\
\text { greater root surface roughness than those in the control group. Er } \\
\text { YAG laser treatment allowed a greater degree of blood component } \\
\text { attachment as compared to exposure to Er Cr YSGG laser. }\end{array}$ \\
\hline $\begin{array}{l}\text { Alhmedi A et al. } \\
2013 \text { [37] }\end{array}$ & $\begin{array}{l}\text { A comparison of cementum alterations following treatment with Er } \\
\text { YAG and CO2 laser using non de-calcified thin histologic sections } \\
\text { was done. Parameters were as follows: } \\
\text { 1. Er YAG laser was used with the following parameters } 40 \mathrm{mg} / \\
\text { pulse }(14.2 \mathrm{~J} / \mathrm{cm} 2 / \text { pulse) and } 25 \mathrm{HZ}(1.0 \mathrm{~W}) \text { under water spray. } \\
\text { 2. Co2 laser irradiation was performed in non contact mode at } 1.0 \mathrm{~W} \\
\text { 3. Ultrasonic scaling was used a control group. }\end{array}$ & $\begin{array}{l}\text { Er YAG treatment group demonstrated micro-irregularities with } \\
\text { whitish slightly ablated surface and thermal changes up to } 20 \text { mi- } \\
\text { crons. In Co2 laser group a carbonization and thermal changes up } \\
\text { to } 140 \text { microns thickness was observed. The authors concluded that } \\
\text { Er YAG laser with water cooling resulted in minimal thermal dam- } \\
\text { age. }\end{array}$ \\
\hline
\end{tabular}




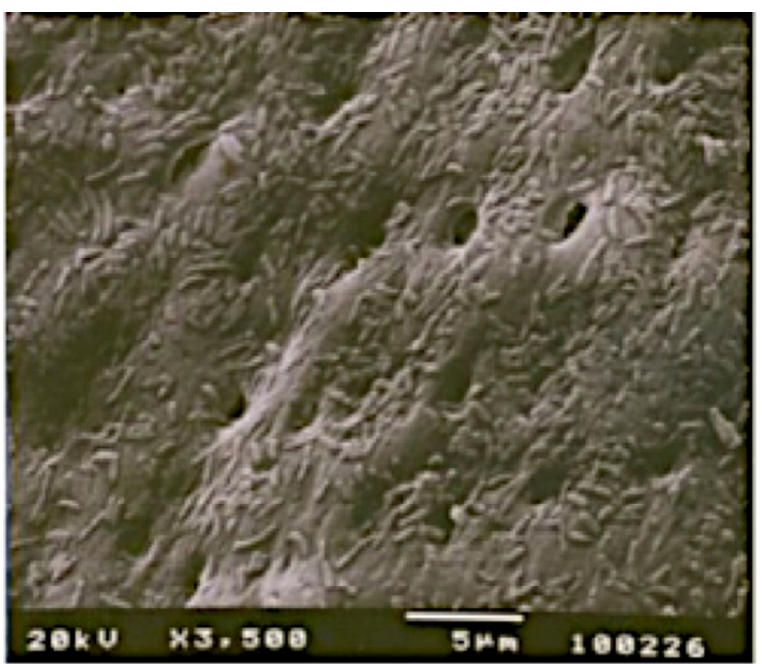

Reproduced with permission from Dr. Ali Cekici. Published in Int J Med Sci 2013; 10(5):560-566. doi: 10.7150/ijms.5233.

Fig. (1). Scanning Electron Microscope picture of periodontally disease root surface treated with citric acid $(25 \%, \mathrm{pH} 1.5$ for $10 \mathrm{sec}-$ onds) demonstrating a complete removal of smear layer and patent dentinal tubules.

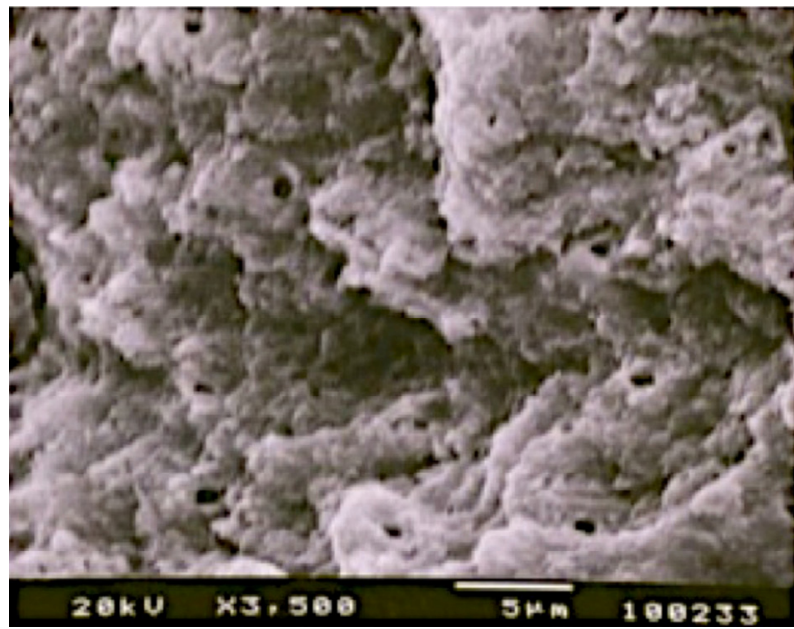

Reproduced with permission from Dr. Ali Cekici. Published in Int J Med Sci 2013; 10(5):560-566. doi: 10.7150/ijms.5233.

Fig. (2). Scanning Electron Microscope picture of periodontally diseased root surface treated with Er YAG laser $\left(15.92 \mathrm{~J} / \mathrm{cm}^{2}\right)$ demonstrating the removal of smear layer, roughened root surfaces and patent dentinal tubules.

Table 3. Studies summarizing the biological reaction of the cells to erbium treated root surfaces.

\begin{tabular}{|c|c|c|}
\hline Author and Year & Study protocol & Findings and Conclusion \\
\hline $\begin{array}{l}\text { Schoop U et al. } \\
2002[46]\end{array}$ & $\begin{array}{l}\text { Assessed the impact of Er YAG laser on root surface morphol- } \\
\text { ogy and its ability to facilitate adhesion of mouse fibroblasts }\end{array}$ & $\begin{array}{l}\text { Er YAG laser irradiated root surface offers better condition for } \\
\text { adherence of mouse fibroblasts }\end{array}$ \\
\hline $\begin{array}{l}\text { Schwarz F et al. } \\
2003 \text { [47] }\end{array}$ & $\begin{array}{l}\text { In vivo effects of Er:YAG laser }(100 \mathrm{~mJ}, 10 \mathrm{~Hz}) \text { on the biocom- } \\
\text { patibility of periodontally diseased root surfaces in cultures of } \\
\text { human periodontal ligament fibroblasts }(\mathrm{PDL}) \text {. }\end{array}$ & $\begin{array}{l}\text { Erbium lasers promote attachment of PDL fibroblasts on previ- } \\
\text { ously diseased root surfaces. The surface structure of Erbium laser } \\
\text { instrumented roots offer better conditions for the adherence of PDL } \\
\text { fibroblasts than scaling and root planing. }\end{array}$ \\
\hline $\begin{array}{l}\text { Crespi R et al. } \\
2006 \text { [49] }\end{array}$ & $\begin{array}{l}\text { Laser }(160 \mathrm{~mJ} / 10 \mathrm{~Hz}) \text { vs Ultrasonic scaler in the treatment of } \\
\text { periodontally diseased teeth. The teeth were incubated in fibro- } \\
\text { blast suspension and cell attachment and density was assessed. }\end{array}$ & $\begin{array}{l}\text { Laser-treated specimens showed a significantly higher cell density } \\
\text { number compared to untreated control surfaces and ultrasonically } \\
\text { treated surfaces. }\end{array}$ \\
\hline $\begin{array}{l}\text { Galli C et al. } 2009 \\
\text { [51] }\end{array}$ & $\begin{array}{l}\text { Cell morphology using periodontal ligament fibroblast culture } \\
\text { investigated by SEM after 3, 6, 24, and } 48 \text { hours of culture. }\end{array}$ & $\begin{array}{l}\text { The surface changes produced a less favorable environment for cell } \\
\text { adhesion or growth, and treated dentin seemed to be more suitable } \\
\text { for periodontal ligament fibroblasts adhesion as compared to hu- } \\
\text { man osteoblast adhesion. }\end{array}$ \\
\hline $\begin{array}{l}\text { Hakki SS et al. } \\
2010[52]\end{array}$ & $\begin{array}{l}\text { Attachment of Periodontal ligament fibroblasts to periodontally } \\
\text { involved root surfaces treated with Erbium laser with short pulse } \\
\text { and long pulse setting. }\end{array}$ & $\begin{array}{l}\text { Short-pulse laser setting may enhance the attachment, spreading, } \\
\text { and orientation of Periodontal ligament cells }\end{array}$ \\
\hline
\end{tabular}


(Table 3) contd....

\begin{tabular}{|c|c|c|}
\hline Author and Year & Study protocol & Findings and Conclusion \\
\hline $\begin{array}{l}\text { de Oliveira GJ } \\
\text { et al. } 2010 \text { [54] }\end{array}$ & $\begin{array}{l}\text { Morphology and attachment of blood components on root sur- } \\
\text { faces irradiated with Er Cr YSGG laser at different angulations. } \\
\text { Laser parameters used were } 1.0 \mathrm{~W}, 20 \mathrm{hz}(140-150 \mathrm{micro} \text { sec- } \\
\text { onds), } 10 \% \text { air and } 15 \% \text { water for } 30 \mathrm{sec}(29.99 \mathrm{~J} / \mathrm{cm} 2 / \mathrm{pulse})\end{array}$ & $\begin{array}{l}\text { The Er Cr YSGG irradiated root surfaces proved to be rougher than } \\
\text { those scaled with manual instruments; irradiation at working tip } \\
\text { angulations of } 45^{\circ} \text { and } 60^{\circ} \text { produced results of attachment of blood } \\
\text { components and root wear comparable with those obtained with } \\
\text { manual instrumentation. }\end{array}$ \\
\hline $\begin{array}{l}\text { Bolortuya G } \\
\text { et al. } 2011 \text { [55] }\end{array}$ & $\begin{array}{l}\text { Comparison of fibroblast cell attachment to } \\
\text { 1. Er YAG laser ( } 30 \mathrm{~mJ} \text { per pulse, } 10 \mathrm{pps}, 60 \mathrm{~s} \text { ) irradiated dentine } \\
\text { vs } \\
\text { 2. L-MTAD group: Laser irradiation with application of a mix- } \\
\text { ture of Doxycycline+ Tetracycline + citric Acid treated dentine } \\
\text { vs } \\
\text { 3. Rc Prep (EDTA gel / cream) vs } \\
\text { 4. Control group (no treatment). } \\
\text { Cell attachment was observed and evaluated using counting } \\
\text { assays and SEM }\end{array}$ & $\begin{array}{l}\text { The authors observed that the number of cells attached to the laser } \\
\text { group was significantly higher than in the Rc Prep and control } \\
\text { groups at } 16 \text { hours. Also the laser group exhibited dendritic cell } \\
\text { extension by fibroblasts as demonstrated by SEM analysis. }\end{array}$ \\
\hline
\end{tabular}

Table 4. Erbium family of lasers vis a vis conventional methods of root modification.

\begin{tabular}{|l|l|l|l|}
\hline S.No & Variables & $\begin{array}{l}\text { Conventional methods } \\
\text { (Scaling and root planing (SRP) } \\
\text { citric acid/ EDTA/Tetracycline/Fibronectin/Emdogain) }\end{array}$ & Erbium family of Lasers \\
\hline \hline 1. & Calculus removal & Yes & Equivalent to SRP \\
\hline 2. & Preservation of cementum & No & Yes \\
\hline 3. & Removal of endotoxin & Yes & Yes \\
\hline 4. & Smear layer removal & Yes & Yes \\
\hline 5. & pH change on root surface & Yes & No \\
\hline 6. & Thermal damage & No & Minimal \\
\hline 7. & Stable fibrin clot formation & Yes & Yes \\
\hline 8 & Cell attachment & Yes & Better than conventional methods \\
\hline 9. & Cost & Low & High \\
\hline 10. & Patient acceptability & Acceptable & Better than conventional methods \\
\hline
\end{tabular}

Erbium lasers are a suitable alternative to conventional methods for root modification.

\section{Root Surface Bio-Modification Prior to Root Coverage Procedures}

Root bio-modification has been performed as an adjunct to root coverage procedures for improving the outcomes. Conventional methods of root bio- modification prior to root coverage include the use of chemical modification agents such as citric acid, tetracycline [58,59]. One of the novel applications of the Er YAG laser has been its use for root bio-modification prior to root coverage procedures. A study by Dilsiz A et al. [60] revealed no significant improvement in the clinical outcomes following adjunctive use of erbium laser for root modification prior to root coverage. A recent systematic review [61] evaluating the effectiveness of adjunctive use of chemical agents and lasers for root biomodification prior to recession coverage reported no additional benefit in terms of clinical parameter improvement. It can be inferred that erbium lasers do not appear to improve the outcomes of root coverage procedures when used as an adjunct.
A recent systematic review and meta analysis by Sgolatra et al. [62] analyzed the efficacy of Erbium laser as compared to scaling and root planing in treatment of chronic periodontitis. The authors observed no statistically significant difference in any of the investigated clinical parameters and attributed this finding to the heterogeneity of the data collected in the five randomized controlled trials included in the meta analysis.

\section{SUMMARY AND CONCLUSION}

The existing literature serves to highlight the promising role of Erbium family of lasers in root bio-modification. The erbium family has a proven anti-bacterial action, predictable calculus removal, minimal root substance removal, and appears to favor cell attachment (when used in combination with acid conditioning or growth factors). A comparative summary of Erbium family of laser vs the conventional techniques for root bio-modification is given in Table 4. In conclusion, Erbium lasers are a useful tool in the periodontist's armamentarium and can be used for root modification. 


\section{CONFLICT OF INTEREST}

The authors confirm that this article content has no conflict of interest.

\section{ACKNOWLEDGEMENTS}

The authors acknowledge the contribution of Ms Cynthia Milton, Lecturer in English, Sri Ramachandra University towards correction of the grammar and language of this manuscript.

\section{REFERENCES}

[1] Offenbacher S, Barros SP, Singer RE, Moss K, Williams RC, Beck JD. Periodontal disease at the biofilm-gingival interface. J Periodontol 2007; 78: 1911-25.

[2] Armitage GC, Christie TM. Structural changes in exposed cementum. II. Electron microscopic observations. J Periodontol Res 1973; 8: $356-65$.

[3] Sottosanti JS. A possible relationship between occlusion, root resorption and the progression of periodontal disease. J West Soc Periodontol 1977; 25: 69.

[4] Aleo JJ, De Renzis FA, Farber PA, Varboncoeur AP. The presence and biologic activity of cementum- bound endotoxin. J Periodontol 1974; 45: 672-5.

[5] Melcher AH. On the repair potential of periodontal tissues. J Periodontol 1976; 47: 256-60.

[6] Polson AM, Caton J. Factors influencing periodontal repair and regeneration. J Periodontol 1982; 53: 617-25.

[7] Hanes PJ, Polson AM, Ladenheim S. Cell and fiber attachment to demineralized dentin from normal root surfaces. J Periodontol 1985; 56: 752-65.

[8] Blomlöf JP, Blomlöf LB, Lindskog SF. Smear removal and collagen exposure after non-surgical root planing followed by etching with an EDTA gel preparation. J Periodontol 1996; 67: 841-5.

[9] Garrett JS, Crigger M, Egelberg J. Effects of citric acid on diseased root surfaces. J Periodontol Res 1978; 13: 155-63.

[10] Froum S, Lemler J, Horowitz R, Davidson B. The use of enamel matrix derivative in the treatment of periodontal osseous defect: a clinical decision tree based on biologic principles of regeneration. Int J Restorative Dent 2001; 21: 437- 49.

[11] Yukna RA, Mellonig JT. Histologic evaluation of periodontal healing in humans following regeneratice therapy with enamel matrix derivative: a 10 case series. J Periodontol 2000; 71: 752-9.

[12] Mariotti A. Efficacy of chemical root surface modifiers in the treatment of periodontal disease. A systematic review. Ann Periodontol 2003; 8: 205-26.

[13] Blomlöf J, Lindskog S. Root surface texture and early cell and tissue colonization after different etching modalities. Eur J Oral Sci 1995; 103: 17-24.

[14] Golub LM. Reduction with tetracyclines of excessive collagen degradation in periodontal and other diseases. NY State Dent $\mathbf{J}$ 1990; 56: 24-6.

[15] Madison JG, Hokett SD. The effects of different tetracyclines on the dentin root surface of instrumented, periodontally involved human teeth: a comparative scanning electron microscope study. J Periodontol 1997; 68: 739-45.

[16] Fernyhough W, Page RC. Attachment, growth and synthesis by human gingival fibroblasts on demineralized or fibronectin-treated normal and diseased tooth roots. J Periodontol 1983; 54: 133-40.

[17] Caffesse RG, Kerry GJ, Chaves ES, et al. Clinical evaluation of the use of citric acid and autologous fibronectin in periodontal surgery. J Periodontol 1988; 59: 565-9.

[18] Carvalho Batista LH, Cezar Sampaio JE, Pilatti GL, Shibli JA. Efficacy of EDTA-T gel for smear layer removal at root surfaces. Quintessence Int 2005; 36: 551-8.

[19] Blomlöf J, Jansson L, Blomlöf L, Lindskog S. Root surface etching at neutral $\mathrm{pH}$ promotes periodontal healing. J Clin Periodontol 1996; 23: 50-5.

[20] Francetti L, Del Fabbro M, Basso M, Testori T, Weinstein R. Enamel matrix proteins in the treatment of intra-bony defects. A prospective 24-month clinical trial. J Clin Periodontol 2004; 31: $52-9$.
[21] Heijl L. Periodontal regeneration with enamel matrix derivative in one human experimental defect. A case report. J Clin Periodontol 1997; 24: 693-6.

[22] [No Authors Listed] American Academy of Periodontology Statement on the Efficacy of Lasers in the Non-Surgical Treatment of Inflammatory Periodontal Disease. J Periodontol 2011; 82: 513-14.

[23] Paghdiwala A. Application of the erbium:YAG laser on hard dental tissues: measurement of the temerature changes and depths of cut. Lasers in Medicine, Surgery, and Dentistry. Proc ICALEO 1988; 64: 192-201.

[24] Keller U, Hibst R. Ablative effect of an Er:YAG laser on enamel and dentin [Article in German]. Dtsch Zahnarztl Z 1989; 44: 600-2.

[25] Schwarz F, Sculean A, Berakdar M, Szathmari L, Georg T, Becker J. In vivo and in vitro effects of an Er: YAG laser, a GaAlAs diode laser, and scaling and root planing on periodontally diseased root surfaces: a comparative histologic study. Lasers Surg Med 2003; 32: 359-66.

[26] Folwaczny M, Heym R, Mehl A, Hickel R. Subgingival calculus detection with fluorescence induced by $655 \mathrm{~nm}$ InGaAsP diode laser radiation. J Periodontol 2002; 73: 597-601.

[27] Aoki A, Miura M, Akiyama F, et al. In vitro evaluation of Er: YAG laser scaling of subgingival calculus in comparison with ultrasonic scaling. J Periodontal Res 2000; 35: 266-77.

[28] Schwarz F, Putz N, Georg T, Reich E. Effect of an Er: YAG laser in periodontally involved root surface: An in vivo and in vitro SEM comparison. Lasers Surg Med 2001; 29: 328-35.

[29] Frentzen M, Braun A, Aniol D. Er:YAG laser scaling of diseased root surfaces. J Periodontol 2002; 73: 524-30.

[30] Eberhard J, Ehlers H, Falk W, Açil Y, Albers HK, Jepsen S. Efficacy of subgingival calculus removal with Er: YAG laser compared to mechanical debridement: an in situ study. J Clin Periodontol 2003; 30: 511-8.

[31] Schwarz F, Bieling K, Venghaus S, Sculean A, Jepsen S, Becker J. Influence of fluorescence-controlled Er:YAG laser radiation, the Vector system and hand instruments on periodontally diseased root surfaces in vivo. J Clin Periodontol 2006; 33: 200-8.

[32] Abed MA, Tawakkoli M, Dehchenari MA, Gutknecht N, Mir M. A comparative SEM study between hand instrument and Er:YAG laser scaling and root planing. Lasers Med Sci 2007; 22: 25-9.

[33] Krause F, Braun A, Brede O, Eberhard J, Frentzen M, Jepsen S. Evaluation of selective calculus removal by a fluorescence feedback-controlled Er:YAG laser in vitro. J Clin Periodontol 2007; 34: 66-71.

[34] Ting CC, Fukuda M, Watanabe T, Aoki T, Sanaoka A, Noguchi T Effects of Er,Cr:YSGG laser irradiation on the root surface: morphologic analysis and efficiency of calculus removal. J Periodontol 2007; 78: 2156-64.

[35] Hakki SS, Berk G, Dundar N, Saglam M, Berk N. Effects of root planing procedures with hand instrument or erbium, chromium:yttrium-scandium-gallium-garnet laser irradiation on the root surfaces: A comparative scanning electron microscopy study. Lasers Med Sci 2010; 25: 345-53.

[36] Oliveira GJ, Theodoro LH, Marcantonio Junior E, Sampaio JE, Marcantonio RA. Effect of Er,Cr:YSGG and Er: YAG laser irradiation on the adhesion of blood components on the root surface and on root morphology. Braz Oral Res 2012; 26: 256-62.

[37] Almehdi A, Aoki A, Ichinose S, et al. Histological and SEM analysis of root cementum following irradiation with Er:YAG and $\mathrm{CO} 2$ lasers. Lasers Med Sci 2013; 28: 203-13

[38] Gaspirc B, Skaleric U. Morphology, chemical structure and diffusion processes of root surface after Er:YAG and Nd:YAG laser irradiation. J Clin Periodontol 2001; 28: 508-16.

[39] Fujii T, Baehni PC, Kawai O, Kawakami T, Matsuda K, Kowashi Y. Scanning electron microscopic study of the effects of Er: YAG laser on root cementum. J Periodontol 1998; 69: 1283-90.

[40] Folwaczny M, George G, Thiele L, Mehl A, Hickel R. Root surface roughness following Er:YAG laser irradiation at different radiation energies and working tip angulations. J Clin Periodontol 2002; 29: 598-603.

[41] Yamaguchi H, Kobayashi K, Osada R, et al. Effects of irradiation of an erbium:YAG laser on root surfaces. J Periodontol 1997; 68: $1151-5$.

[42] Folwaczny M, Aggstaller H, Mehl A, Hickel R. Removal of bacterial endotoxin from root surface with Er: YAG laser. Am J Dent 2003; 16: 3-5. 
[43] Akiyama F, Aoki A, Miura-Uchiyama M, et al. In vitro studies of the ablation mechanism of periodontopathic bacteria and decontamination effect on periodontally diseased root surfaces by erbium:yttrium-aluminum-garnet laser. Lasers Med Sci 2011; 26: 193-204.

[44] Theodoro LH, Zezell DM, Garcia VG, et al. Comparative analysis of root surface smear layer removal by different etching modalities or erbium:yttrium-aluminum-garnet laser irradiation. A scanning electron microscopy study. Lasers Med Sci 2010; 25: 485-91.

[45] Cekici A, Maden I, Yildiz S, San T, Isik G. Evaluation of blood cell attachment on Er: YAG laser applied root surface using scanning electron microscopy. Int J Med Sci 2013; 10: 560-6.

[46] Schoop U, Moritz A, Kluger W. Changes in root surface morphology and fibroblast adherence after Er: YAG laser irradiation. JOLA 2002; 2: 83-93.

[47] Schwarz F, Aoki A, Sculean A, Georg T, Scherbaun W. In vivo effects of an Er: YAG laser, an ultrasonic system, scaling and root planing in biocompatibility of periodontally diseased root surfaces in cultures of human periodontal ligament fibroblasts. Lasers Surg Med 2003; 33: 140-47.

[48] Feist IS, De Micheli G, Carneiro SR, Eduardo CP, Miyagi S, Marques MM. Adhesion and growth of cultured human gingival fibroblasts on periodontally involved root surfaces treated by Er:YAG laser. J Periodontol 2003; 74: 1368-75.

[49] Crespi R, Romanos GE, Cassinelli C, Gherlone E. Effects of Er: YAG laser and ultrasonic treatment on fibroblast attachment to root surfaces: an in vitro study. J Periodontol 2006; 77: 1217-22.

[50] Theodoro LH, Sampaio JE, Haypek P, Bachmann L, Zezell DM, Garcia VG. Effect of Er: YAG and Diode lasers on the adhesion of blood components and on the morphology of irradiated root surfaces. J Periodontal Res 2006; 41: 381-90.

[51] Galli C, Passeri G, Cacchioli A, et al. Effect of laser-induced dentin modifications on periodontal fibroblasts and osteoblasts: a new in vitro model. J Periodontol. 2009; 80: 1648-54.

[52] Hakki SS, Korkusuz P, Perk G, et al. Comparison of Er: CR: YSGG and hand instrumentation on the attachment of periodontal ligament fibroblasts to periodontally diseased root surfaces: an in vitro study. J Periodontol 2010; 81: 1216-25.

[53] Galli C, Macaluso GM, Elezi E, et al. The effects of Er: YAG laser treatment on titanium surface profile and osteoblastic cell activity: an in vitro study. J Periodontol 2011; 82: 1169-77.

[54] de Oliveira GJ, Sampaio JE, Marcantonio RA. Effects of Er,Cr:YSGG laser irradiation on root surfaces for adhesion of blood components and morphology. Photomed Laser Surg 2010; 28: 751-6.

[55] Bolortuya G, Ebihara A, Ichinose S, et al. Initial fibroblast attachment to Erbium: YAG laser-irradiated dentine. Int Endod J 2011; 44: 1134-44.

[56] Maruyama H, Aoki A, Sasaki KM, et al. The effect of chemical and/or mechanical conditioning on the Er:YAG laser-treated root cementum: analysis of surface morphology and periodontal ligament fibroblast attachment. Lasers Surg Med 2008; 40: 211-22.

[57] Belal MH, Watanabe H, Ichinose S, Ishikawa I. Effect of Er:YAG laser combined with rhPDGF-BB on attachment of cultured fibroblasts to periodontally involved root surfaces. J Periodontol 2007; 78: 1329-41.

[58] Caffesse RG, De LaRosa M, Garza M, Munne-Travers A, Mondragon JC, Weltman R. Citric acid demineralization and subepithelial connective tissue grafts. J Periodontol 2000; 71: 568-72.

[59] Bittencourt S, Ribeiro Edel P, Sallum EA, Sallum AW, Nociti FH Jr., Casati MZ. Root surface bio-modification with EDTA for the treatment of gingival recession with a semi-lunar coronally repositioned flap. J Periodontol 1999; 70: 1695-701.

[60] Dilsiz A, Aydin T, Yavuz MS. Root surface biomodification with an Er:YAG laser for the treatment of gingival recession with subepithelial connective tissue grafts. Photomed Laser Surg 2010; 28: 511-7.

[61] Oliveira GH, Muncinelli EA. Efficacy of root surface biomodification in root coverage: a systematic review. J Can Dent Assoc 2012; 78: c122.

[62] Sgolastra F, Petrucci A, Gatto R, Monaco A. Efficacy of Er: YAG laser in the treatment of chronic periodontitis: systematic review and meta-analysis. Lasers Med Sci 2012; 27: 661-73.

(C) Lavu et al.; Licensee Bentham Open.

This is an open access article licensed under the terms of the Creative Commons Attribution Non-Commercial License (http://creativecommons.org/licenses/by-nc/3.0/) which permits unrestricted, non-commercial use, distribution and reproduction in any medium, provided the work is properly cited. 